Artículo Científico Original

\title{
TRABALHO ESCRAVO: CARACTERIZAÇÃO JURÍDICA DOS MODOS TÍPICOS DE EXECUÇÃO
}

José Claudio Monteiro de Brito Filho 
TRABALHO ESCRAVO:

CARACTERIZAÇÃO

JURÍDICA DOS MODOS

TíPICOS DE EXECUÇÃO
SLAVE LABOR: LEGAL

CHARACTERIZATION OF

THE TYPICAL EXECUTION

MODES

José Claudio Monteiro de Brito Filho

Doutor em Direito das Relações Sociais pela Pontifícia Universidade Católica de São Paulo (PUC/SP). Professor da Universidade Federal do Pará e da Universidade da Amazônia. jclaudiobritofilho@gmail.com.

\section{RESUMO}

Artigo que procura fazer a caracterização jurídica dos modos típicos de execução do trabalho em condições análogas à de escravo. O texto, a partir deste objetivo geral, está dividido, basicamente, em duas partes, além do item inicial, em que se contextualiza a discussão, e da conclusão: em primeiro momento são apresentados os elementos básicos para a compreensão do tipo descrito no artigo 149, do Código Penal Brasileiro, para, em seguida, ser feita a caracterização dos modos típicos de execução do trabalho escravo, que são o trabalho forçado, a jornada exaustiva, o trabalho em condições degradantes, e a restrição de locomoção em razão de dívida contraída.

Palavras-chave: Trabalho escravo. Caracterização jurídica. Modos típicos de execução.

\section{ABSTRACT}

Article which seeks to make the legal characterization of the typical execution modes of labor in analogous conditions to slavery. The text, from this overall purpose, is basically divided into two parts, in addition to the initial item, where the discussion is seen in context, and completion: firstly, the basic elements for understanding the type as described in Article 149 of the Brazilian Criminal Code, so then the characterization of the typical execution modes can be made which are bonded labor, exhausting workday, degrading working conditions, mobility restriction due to debt bondage.

Key words: Slave labor. Legal Characterization. Typical execution modes.

\section{Contextualizando a discussão}

Temos nos preocupado nos últimos tempos em discutir o ilícito penal, com repercussões na esfera trabalhista, definido como "trabalho em condições análogas à de escravo", de uma forma mais abrangente. É que, basta uma leitura nos textos e decisões a respeito para verificar que os penalistas tratam da questão de uma for- ma, e os juslaboralistas de outra completamente diversa.

É como se estivéssemos diante de dois fenômenos distintos, quando os fatos que dão origem ao enquadramento do ponto de vista penal e trabalhista são rigorosamente os mesmos.

É certo que, na perspectiva da repressão pela via judicial os focos são distintos: na 
esfera penal, a preocupação principal é com o autor do delito; na esfera trabalhista, de outra banda, a preocupação é com as vítimas, reduzidas à condição análoga à de escravo.

Ainda assim, tudo gira em torno dos mesmos fatos, e não há motivos que justifiquem, do ponto de vista do Direito, enquadramentos diversos, salvo quando as diferentes preocupações levam a olhares também distintos, em razão de concepções jurídicas diferentes, o que vem ocorrendo.

Assim, é que, em textos publicados ou em vias de publicação, procuramos discutir a nova sistemática jurídica do trabalho escravo no Brasil, assim como a caracterização jurídica de seus principais modos de execução'. Nossa ideia é ajudar a construir doutrina que reconheça o ilícito como único, caracterizando-o dessa forma, e permitindo sua repressão em diferentes esferas, a partir da mesma investigação e do mesmo enquadramento.

É que, isto é certo, a repressão inicial ao trabalho em condições análogas à de escravo continuará a ser feita a partir das fiscalizações empreendidas pelos auditores fiscais do trabalho, com a presença de membro do Ministério Público do Trabalho e da Polícia Federal. São desse ato de fiscalização que deverão surgir tanto as ações trabalhistas para reparar os direitos lesados dos trabalhadores, como as ações penais para a responsabilização dos autores do delito.

Para isso, é preciso que a caracterização jurídica dos fatos atenda às peculiaridades das duas esferas, levando em conta que $\circ$ enquadramento deverá servir, de uma só vez, para a repressão nas esferas penal e trabalhista.

Ver, por exemplo, no nosso Trabalho decente (2010, p. 61-81); e em texto denominado Jornada exaustiva e condições degradantes de trabalho: caracterização, publicado na obra coletiva Direito penal e democracia, (2010, p. 259-273).
Neste texto, dando continuidade aos nossos esforços, procuraremos, depois de apresentarmos alguns elementos essenciais para a compreensão genérica do ilícito, caracterizar, no plano do Direito, agora de forma reunida, os modos típicos de execução do trabalho escravo e que, como veremos em classificação mais adiante, são: 0 trabalho forçado; a jornada exaustiva; as condições degradantes de trabalho; e a restrição de locomoção por dívida contraída.

\section{Breves considerações a respeito do tipo descrito no artigo 149 do Código Penal}

Para isso, antes é preciso compreender a profunda mudança que ocorreu com $\circ$ artigo 149 do Código Penal Brasileiro (CP) por força da Lei $n^{\circ} 10.803$, de 11 de dezembro de 2003². O artigo 149 dispunha, na redação anterior, o seguinte: "Art. 149. Reduzir alguém à condição análoga à de escravo. Pena - reclusão, de 2 (dois) a 8 (oito) anos".

Alterado, passou a dispor da seguinte forma:

Art. 149. Reduzir alguém a condição análoga à de escravo, quer submetendo-o a trabalhos forçados ou a jornada exaustiva, quer sujeitando-o a condições degradantes de trabalho, quer restringindo, por qualquer meio, sua locomoção em razão de dívida contraída com o empregador ou preposto: Pena - reclusão, de dois a oito anos, e multa, além da pena correspondente à violência.

$\S 1^{\circ}$ Nas mesmas penas incorre quem: I - cerceia o uso de qualquer meio de transporte por parte do trabalhador, com o fim de retê-lo no local de trabalho;

2 O que temos procurado fazer sempre que há uma oportunidade, como agora, até porque é preciso fazer essa exposição inicial para a exata compreensão do modo de execução em estudo. 
II - mantém vigilância ostensiva no local de trabalho ou se apodera de documentos ou objetos pessoais do trabalhador, com o fim de retê-lo no local de trabalho.

$\S 2^{\circ}$ A pena é aumentada de metade, se o crime é cometido:

I - contra criança ou adolescente;

II - por motivo de preconceito de raça, cor, etnia, religião ou origem.

O que era tipo penal apresentado de forma sintética passou a ser definido de forma analítica. Isso, para alguns, representou ampliação do tipo penal $^{3}$, pela também ampliação do bem jurídico protegido; mas, para outros, representou restrição, capaz até de transformar o crime de comum para especial quanto ao sujeito passivo, como entende Bitencourt. Da mesma forma, para esse autor (BITENCOURT, 2009, p. 405), o que continha um modo ou forma de execução livre, agora só pode ser praticado nos termos estritos do disciplinado rigidamente na lei, com o que forçosamente temos de concordar.

Nesse sentido, o tipo penal, que na forma sintética não indicava os modos de execução, na nova versão fez isto, incluindo alguns que fogem à visão tradicional a respeito do trabalho em condições análogas à de escravo, exigindo da doutrina uma caracterização desses modos, o que ainda não ocorreu, em sua totalidade, até porque também pairam dúvidas até em relação ao tipo, genericamente falando.

Por esse último motivo, antes de discutirmos a caracterização dos modos de execução, precisamos fazer considerações a respeito do tipo penal, como já fizemos em textos anteriores, conforme informado anteriormente.

Situando o artigo 149 no Código Penal, esse dispositivo está inserto na Parte
Especial, que trata dos crimes em espécie, no Título I, relativo aos crimes contra a pessoa. Nesse Título, encontra-se no Capítulo VI - dos crimes contra a liberdade individual, na Seção I, que trata dos crimes contra a liberdade pessoal, e que reúne, além da redução de alguém à condição análoga à de escravo, os crimes de constrangimento ilegal e de sequestro e cárcere privado.

Essa localização é importante para que se discuta qual(is) o(s) bem(ns) jurídico(s) principalmente protegido(s), e contra o(s) qual(is) se atenta, no caso da redução de alguém à condição análoga à de escravo.

Uma leitura superficial daria a impressão de que o bem maior é a liberdade do indivíduo e, cumpre reconhecer, até a alteração do artigo 149 do CP pela Lei $n^{\circ} 10.803 / 2003$, essa era a concepção dominante, para não dizer pacífica.

Ocorre que a alteração feita não deixa dúvidas de que não há o crime de redução à condição análoga à de escravo somente quando a liberdade da pessoa é, diretamente, estritamente, suprimida. Pelo contrário, há hipóteses em que não se discute de forma direta - talvez se deva dizer, de forma principal - a supressão da liberdade do ser humano, como na jornada exaustiva e nas condições degradantes de trabalho, pois há bem maior a proteger, nesses casos, que a liberdade 4 .

Não que a liberdade não seja considerada, também nessas hipóteses, e é assim que se deve ler, por exemplo, os ensinamentos de Capez (2009, p. 345), que afirma: "Protege a lei penal, aqui, o status libertatis, ou seja, a liberdade no conjunto de suas manifestações". Não é só ela, todavia, que está em discussão, como bem entende Rogério Greco. Este autor 
(GRECO, 2008, P. 545), após indicar que o bem juridicamente protegido é a liberdade da vítima, ensina que, quando a lei penal refere-se a condições degradantes de trabalho, existem outros bens juridicamente protegidos: "a vida, a saúde, bem como a segurança do trabalhador, além de sua liberdade".

Ainda assim, a proteção da liberdade está presente sempre, de forma ampla, pois, como se irá defender mais adiante, o tipo penal exige, para sua caracterização, a partir de qualquer das condutas nele descritas, uma relação de sujeição que direta ou indiretamente atinge, fere a liberdade da pessoa.

De qualquer sorte, como defende Bitencourt (2009, p. 398), a conduta descrita no tipo penal "fere, acima de tudo, - princípio da dignidade humana, despojando-o de todos os seus valores ético-sociais, transformando-o em res, no sentido concebido pelos romanos".

É o que temos defendido, desde algum tempo, no sentido de que a alteração do artigo 149 do Código Penal produziu mudança significativa a respeito do bem jurídico principalmente protegido, que passou da liberdade para o atributo maior do homem, que é a sua dignidade ${ }^{5}$, na versão contemporânea, e que é baseada na visão e fundamentação que the emprestou Kant ${ }^{6}$.

Kant (2003, p. 77), fazendo uma divisão entre os seres, em reino ideal por ele concebido, e que denomina "reino dos fins", afirma:

5 Não vou entrar aqui na discussão a respeito de ser a dignidade um bem que independe, para seu reconhecimento, do Direito. $O$ que quero enfatizar aqui é que a dignidade é um bem reconhecido pelo Direito, como, por exemplo, no artigo $1^{\circ}$, III, da Constituição da República, que a elege como um dos fundamentos da República.

6 Não obstante se possa observar a influência Kantiana em autores diversos, e que constituem figuras de expressão na Filosofia e na Teoria do Direito, como Ronald Dworkin, Kant sempre é alvo de constantes críticas. Uma delas diz respeito ao fato de não ter apresentado uma definição concreta de dignidade. A esse respeito é possivel - e de forma singela, pois é o que comporta este ensaio - dizer que Kant estabeleceu o parâmetro necessário para a compreensão da dignidade, ao distingui-la do preço, além de ter fixado fundamento também concreto para esse atributo do ser humano: a razão.
No reino dos fins tudo tem ou um preço ou uma dignidade. Quando uma coisa tem preço, pode-se pôr em vez dela qualquer outra coisa como equivalente; mas quando uma coisa está acima de todo o preço, e, portanto não permite equivalente, então ela tem dignidade.

A dignidade, dessa feita, deve ser considerada como atributo do ser humano, algo que dele faz parte e, portanto, o faz merecedor de um mínimo de direitos, e é ela que, principalmente, é violada quando tipificado o crime de redução à condição análoga à de escravo, pois o que ocorre é o não respeito a esse atributo do ser humano, que é tratado como coisa, qualquer que seja o modo de execução, com a negação de sua dignidade e, por consequência, de sua condição de ser humano?.

Note-se que essa conclusão já podia ser encontrada antes da alteração do artigo 149, quando o tipo penal era apresentado de forma lacônica. É que, não se pode considerar que alguém seja reduzido à condição análoga à de escravo somente quando ocorre, na forma tradicional que conhecemos, a perda de sua liberdade, pois, para que o crime se tipifique, o que importa e basta é que a relação de prestação de serviços entre os sujeitos ativo e passivo seja de tal ordem que o primeiro passe a ter domínio sobre o segundo, de forma que a vontade desse segundo seja anulada, ou porque a vontade desse segundo foi anulada.

Como diz Bitencourt (2009, p. 400), "a liberdade protegida pelo art. 149 não se limita à autolocomoção, mas principalmente procura impedir o estado de sujeição da vítima ao pleno domínio de

7 Ver a respeito o nosso "Trabalho com redução à condição análoga à de escravo: análise a partir do trabalho decente e de seu fundamento, a dignidade da pessoa humana" (In VELLOSO e FAVA, 2006), especialmente na página 135. Ver também, a respeito da concepção Kantiana, os ensinamentos de Rabenhorst (2001. p. 32-34) 
alguém", pouco importando os modos ou meios de execução que, como também ensina o autor citado, "são os mais variados possíveis".

Isso seguramente não está distante da concepção que se deve ter do delito de plágio, como também se denomina o tipo do artigo 149 do Código Penal.

Vejamos, a respeito, $06^{\circ}$ parágrafo do item 51 da Exposição de Motivos da Parte Especial do Código Penal, assinada por Francisco Campos, então Ministro da Justiça e Negócios Interiores, em 4 de novembro de 1940:

No art. 149, é prevista uma entidade ignorada do Código Vigente: o fato de reduzir alguém, por qualquer meio, à condição análoga à de escravo, isto é, suprimir-lhe, de fato, o status libertatis, sujeitando-o o agente ao seu completo e discricionário poder. É o crime que os antigos chamavam plagium. Não é desconhecida a sua prática entre nós, notadamente em certos pontos remotos de nosso hinterland.

A propósito, Bitencourt (2009, p. 397 398), indicando que há uma grande diferença entre o tipo penal do artigo 149 e o crime de plágio, dos romanos, explica esse último delito, da seguinte forma:

Quando o Direito Romano proibia a condução da vítima, indevidamente, ao estado de escravidão, cujo nomen iuris era plagium, o bem jurídico tutelado não era propriamente a liberdade do indivíduo, mas o direito de domínio que alguém poderia ter ou perder por meio dessa escravidão indevida.

Ainda a respeito do plágio, Pierangeli (2007, p. 156) afirma que "A palarra plagium, etimologicamente, vem do verbo plagiare, que na Roma antiga significava a compra de um homem livre sabendo que o era, e retê-lo em servidão ou utilizá-lo como próprio servo".

Voltando à forma de ver o tipo do artigo 149, essa ampliação na consideração a respeito do bem juridicamente protegido, todavia, não significa só considerar a dignidade, mas sim considerá-la $\circ$ bem maior a proteger. Por outro lado, não significa desconsiderar a liberdade, retomando a conclusão antes apresentada, e como veremos.

Para isso, conveniente verificar as hipóteses em que, atualmente, pelo artigo 149, tem-se o crime de redução à condição análoga à de escravo.

Rogério Greco (2008, p. 542), tratando do que chama de "maneiras que, analogamente, fazem com que o trabalho seja comparado a um regime de escravidão", indica que isso ocorre quando alguém: obriga outrem a trabalhos forçados; impõe jornada exaustiva de trabalho; sujeita alguém a condições degradantes de trabalho; e, restringe, por qualquer meio, a locomoção de alguém em razão de dívida contraída.

De forma mais esquemática, as hipóteses em que isso pode ocorrer, caso se deseje classificá-las, podem ser divididas em:

a) trabalho escravo típico, que contempla o trabalho forçado ou em jornada exaustiva, o trabalho em condições degradantes e, o trabalho com restrição de locomoção, em razão de dívida contraída (chamado comumente de servidão por dívida); e,

b) trabalho escravo por equiparação, que se verifica nas hipóteses de retenção no local de trabalho, por cerceamento do uso de qualquer meio de transporte, e de manutenção de vigilância ostensiva ou re- 
tenção de documentos ou objetos de uso pessoal do trabalhador.

Essa classificação, que resultou de disposição legal mais analítica, como vimos, trouxe duas vantagens. Primeiro, ampliou - rol de hipóteses que caracterizam o trabalho escravo, dando feição mais consentânea com o objetivo de proteger 0 que, de fato, é o mais importante, que é a dignidade da pessoa humana. Segundo, tornou mais fácil a tipificação do ilícito, o que a sintética, lacônica redação anterior não permitia.

Agora é mais simples identificar, no caso concreto, se a situação encontrada nas investigações e fiscalizações deve ser enquadrada como trabalho em condições análogas à de escravo ou não, o que garante maior segurança para as condutas a adotar ${ }^{8}$. Maior, mas, não total segurança, pois ainda resta por fazer um esforço maior para identificar, com precisão, as condutas que caracterizam os modos de execução. Já chegaremos lá, pois é preciso ainda voltar à discussão inicial, da caracterização genérica do tipo penal.

Nesse aspecto é preciso dizer que, por mais que se queira, às vezes com algum sucesso, relacionar o tipo lá descrito a antecedentes históricos como a escravidão dos negros, que conhecemos no Brasil até os momentos finais do Século XIX, ou à servidão, presente na Europa alguns séculos antes, pensamos que, se há antecedente a relacionar, esse deve ser mesmo o plágio dos Romanos, e que claramente inspirou - legislador penal, como visto, embora, como adverte Bitencourt, em citação mais acima, não haja total correspondência.

\footnotetext{
8 Cabe relembrar aqui Cezar Roberto Bitencourt (2009, p. 406), para quem "agora há limitação estrita aos modos de execução, que estão vinculados", o que produz "uma abolitio criminis em relação a todo e qualquer outro modo ou forma de conduta que não seja abrangido pela relação numerus clausus da nova definição legal". Minha discordância do defendido pelo autor, nesse caso, tem um vié pragmático: a enumeração das hipóteses, embora possa, em tese, restringir o tipo penal, por outro lado permite enquadramento mais preciso, além do fato de que abriu espaço para algumas condutas que poderiam até ser deduzidas, mas não eram consideradas.
}

Assim, o que temos, no crime de redução da pessoa à condição análoga à de escravo é, claramente, a subjugação do ser humano, que é naturalmente livre, a uma condição que lhe impõe, por outrem, uma relação de domínio extremado, e que atenta contra a sua condição de pessoa. Isso permite, desde logo, duas conclusões.

A primeira, de que o crime em comento é uma violação direta ao principal atributo do ser humano, que é sua dignidade, pois qualquer das condutas descritas no artigo 149 é a negação desse atributo, reduzindo a pessoa à condição de coisa.

Isso vai acontecer tanto quando ao ser humano é imposto o trabalho forçado ou uma jornada exaustiva de trabalho, como quando the são reservadas condições degradantes de trabalho, ou ainda nas demais hipóteses catalogadas no artigo, como no caso da restrição à locomoção por dívida contraída.

Essa é a conclusão mais importante, mas não a única. É que, como dissemos, não é o fato de considerar que a dignidade da pessoa humana é o bem jurídico principalmente tutelado que vai fazer com que não se leve em consideração o aspecto da liberdade. Ocorre que não é a liberdade no sentido tradicional vinculado à antiga escravidão, de o escravo acorrentado e vigiado vinte e quatro horas por dia, com restrições à sua livre locomoção, que deve ser visualizada em todas as hipóteses ou modos de execução, embora isso possa ocorrer.

Na verdade, o que deve ser observado é - grau de domínio que exerce o tomador dos serviços em relação ao trabalhador; a sujeição que $\circ$ primeiro impõe ao segundo. Nos casos em que habitualmente se denuncia a prática do trabalho escravo, no Brasil, isso fica claro. São trabalhadores migrantes, como nas plantações de cana-de-açúcar e nas fazendas de gado, 
e às vezes imigrantes, como é o caso dos bolivianos que trabalham na indústria de confecção; arregimentados em local distante de onde vai haver a prestação de serviços; sem perspectiva de realizar outra atividade que garanta sua sobrevivência; sem o grau de conhecimento mínimo que lhes permita questionar, ainda que intimamente, as péssimas condições de trabalho que lhes são oferecidas.

Mais. Por conta de todas essas condições, são altamente influenciáveis e, no mais das vezes, levados a crer que o que thes é exigido é permitido por lei. Tudo isso leva a estado em que sua vontade é anulada, "criando" situação de sujeição tal que não se pode, sob qualquer pretexto, falar em outra condição que não a de clara violação à sua liberdade.

A segunda conclusão, então, para caracterizar o trabalho em condições análogas à de escravo, é que deve haver a sujeição do trabalhador ao tomador de serviços, e que se vai materializar, em graus variados, em todas as hipóteses de redução da pessoa à condição análoga à de escravo.

Isso, pensamos, deve ser perfeitamente identificado nos relatórios apresentados tanto pela autoridade administrativa do trabalho, como pela autoridade policial, assim como deve ser de indicação obrigatória nas ações, penais ou trabalhistas, propostas pelo Ministério Público.

Por fim, é preciso considerar o fato de que, para ocorrer qualquer hipótese do artigo 149 do Código Penal, ou seja, para que se identifique o trabalho escravo como conhecemos no Brasil, na atualidade, é preciso que se esteja diante de uma relação de trabalho" - realizada ao arrepio da legislação que a rege, e tipi-

\footnotetext{
9 Observe-se que, pouco importa se esta relação está mascarada, encoberta formalizada como, por exemplo, um (falso) contrato de arrendamento ou de parceria. Há relação de trabalho quando um ser humano presta serviços a outrem em troca de um bem com expressão econômica. A relação jurídica de trabalho, assim como a relação jurídica de emprego, é baseada na realidade dos fatos, não na forma.
}

ficada como um ilícito penal, mas, ainda assim, uma relação de trabalho.

Passeando rapidamente pelos autores, Nucci $(2008$, p. 690) afirma que os sujeitos ativos do delito são, como regra, 0 empregador e seus prepostos e, o sujeito passivo, somente a pessoa "vinculada a uma relação de trabalho. Bitencourt (2009, p. 400), de sua parte, ensina que, a partir da alteração do artigo 149 , só pode ser sujeito passivo quem for trabalhador, devendo haver o que denomina de "relação de prestação de serviço". Greco (2008, p. 545) por fim, segue na mesma linha, ao entender que, a partir da Lei $n^{\circ} 10.803 / 2003$, "foram delimitados os sujeitos ativo e passivo do delito [...], devendo, agora, segundo entendemos, existir entre eles relação de trabalho".

Pode-se dizer então que, qualquer que seja o modo de execução, o crime de reduzir alguém à condição análoga à de escravo ocorre em relação de trabalho mantida entre trabalhador e o tomador de seus serviços, com violação da dignidade e da liberdade do primeiro ${ }^{10}$.

\section{Caracterização jurídica dos modos típicos de execução do crime de trabalho escravo}

Essa caracterização genérica, todavia, não soluciona em definitivo o problema da identificação mais precisa do tipo penal. É que o ilícito do artigo 149 do Código Penal é identificado, hoje em dia, como vimos, de forma analítica, apresentando sete modos de execução, quatro típicos e três por equiparação.

\footnotetext{
10 A esse respeito, Ela Wiecko de Castilho, em texto denominado Em busca de uma definição jurídico-penal de trabalho escravo (In Trabalho escravo no Brasil contemporâneo, 1999, p. 84), e tratando genericamente das formas de prestação de serviços que possam caracterizar o trabalho em condições análogas à de escravo, e depois de descrever algumas práticas específicas, afirma que deve ser considerada "toda outra situação, qualquer que seja seu nome e independentemente da aparência que possa apresentar, que equivalha, ou se assemelhe, à escravidão ou à servidão, isto é, que negue ou menospreze a dignidade e a liberdade essencial da pessoa individual", enfatizando a violação aos princípios fundamentais que aludimos acima.
} 
É preciso compreendê-los, então, pois é a partir deles que a tipificação ocorrerá. É o que tentaremos fazer a seguir, exclusivamente em relação aos quatro primeiros, os modos típicos de execução.

\subsection{Trabalho forçado}

O primeiro deles é o trabalho forçado, aparentemente $\circ$ mais fácil de definir. Seria assim se, em torno desta espécie ou modo de execução não houvesse ocorrido, na mudança da situação antiga para a nova, no que diz respeito à redação do artigo 149, do Código Penal, alguns equívocos no aspecto conceitual.

Até a nova redação do artigo 149 , como vimos no item 2, a lacônica descrição do ilícito conduzia ao entendimento, incorreto, de que a redução da pessoa à condição análoga à de escravo significava exclusivamente uma restrição à liberdade, não obstante desde a Exposição de Motivos da Parte Especial do Código Penal, em 1940, já fosse cabível vislumbrar o ilícito em um espectro maior.

De qualquer sorte, essa ligação direta e restrita com a falta de liberdade permitia relacionar o ilícito do artigo $149 \mathrm{com}$ o disposto nas Convenções 29 e 105, da Organização Internacional do Trabalho - OIT, que tratam do trabalho forçado ou obrigatório, dispondo a primeira, no artigo $2^{\circ}, 1$, o seguinte:

Para fins desta Convenção, a expressão "trabalho forçado ou obrigatório" compreenderá todo trabalho ou serviço exigido de uma pessoa sob a ameaça de sanção e para o qual não se tenha oferecido espontaneamente.

O ilícito do artigo 149 do Código Penal Brasileiro, então, na perspectiva do trabalho, era claramente uma espécie da conduta rejeitada pela OIT, junto com outras, como o trabalho obrigatório como medida de coerção ou de educação política, como se encontra no artigo $1^{\circ}$, "a", da convenção 105.

A alteração do artigo 149, todavia, em 2003, que ofereceu ao ilícito uma amplitude maior, gerou insegurança em relação ao que parecia consolidado, que era a relação entre o trabalho forçado definido pela OIT e o trabalho escravo definido como crime na legislação penal brasileira.

É que a introdução, de forma expressa, de outros modos de execução que não o que se imaginava estar exclusivamente indicado no dispositivo legal, o trabalho obrigatório, em princípio desequilibrava a relação antes estabelecida entre norma de Direito Internacional e norma do Direito Interno.

Hoje se pode afirmar que esse desequilíbrio não ocorre, uma vez que, ainda que em intensidades diversas, a falta de liberdade continua a existir em todos os modos de execução, desde que entendida sob a forma de um domínio extremado do tomador de serviços em relação ao trabalhador, em todos os casos motivado pela situação de miséria, de extrema necessidade, do último.

O primeiro modo de execução típico e de que estamos agora a tratar, o trabalho forçado, então, difere dos demais, que veremos a seguir, mais por uma questão de intensidade, pois nesta hipótese a obrigatoriedade na prestação do serviço é a característica determinante.

Nesse sentido, deve-se caracterizar o trabalho forçado como espécie do crime de reduzir alguém à condição análoga à de escravo a partir dos seguintes elementos: 1. a existência de uma relação de trabalho entre os sujeitos ativo (tomador de serviços) e passivo (trabalhador) do ilícito; 2. O fato de o trabalho ser prestado 
de forma compulsória, independentemente da vontade do trabalhador, ou com a anulação de sua vontade, por qualquer circunstância que assim o determine.

A partir desses elementos, trabalho forçado define-se como:

O trabalho que for prestado por trabalhador a tomador de serviços em caráter obrigatório, quando não decorrer da livre vontade do primeiro, ou quando a obrigatoriedade for consequência, por qualquer circunstância, da anulação de sua vontade.

\subsection{Jornada exaustiva}

segundo modo é a jornada exaustiva.

Para Nucci (2008, p. 691), a jornada exaustiva se caracteriza pelo "trabalho diário que foge às regras da legislação trabalhista, exaurindo o trabalhador", sendo que, para que se configure, é preciso que "o patrão submeta (ou seja, exija, subjugue, domine pela força) $\circ$ seu empregado a tal situação".

Já Greco (2008, p. 543) defende que jornada exaustiva de trabalho é a que esgota as forças do trabalhador, "minando sua saúde física e mental". Na mesma linha, Prado (2008, p. 64) fala em uma jornada "esgotante, além do que é considerado aceitável".

Cícero Rufino Pereira (2007, p. 59), de sua banda, indica que a jornada exaustiva "expõe o trabalhador à falta de segurança e riscos para sua saúde," pelo fato de que "o trabalho em longas jornadas deixa o ser humano com os reflexos e raciocínio mais lentos, submetendo o obreiro a riscos de acidentes e problemas de saúde relacionados à fadiga".

É possível, a partir dessas descrições, fazer a caracterização do que seja jornada exaustiva a partir de quatro elementos: 1. a existência de uma relação de trabaIho; 2 . o estabelecimento de uma jornada que ultrapasse os limites legais estabelecidos; 3 . a capacidade de essa jornada causar prejuízos à saúde física e mental do trabalhador, esgotando-o; 4. a imposição dessa jornada, contra a vontade do trabalhador, ou com a anulação de sua vontade, por qualquer circunstância que assim o determine"1.

Nesse sentido, acreditamos que jornada exaustiva, para os fins do art. 149 do Código Penal, deve ser definida como:

Jornada de trabalho imposta a alguém por outrem em relação de trabalho, além dos limites legais extraordinários estabelecidos na legislação de regência, e/ou capaz de causar prejuízos à sua saúde física e mental, e decorrente de uma situação de sujeição que se estabelece entre ambos, de maneira forçada ou por circunstâncias que anulem a vontade do primeiro.

\subsection{Condições degradantes de trabalho}

Já para as condições degradantes de trabalho, ou, como se denomina correntemente, o trabalho em condições degradantes, o esforço há de ser maior. É que não há uma situação única, como no caso, por exemplo, da jornada exaustiva.

Para isso, verificaremos primeiro o que dizem os autores a respeito.

Melo (setembro/2003, p. 15), para descrever as condições degradantes de trabalho, relaciona, acertadamente, péssi-

11 Duas situações em que a vontade é anulada, e que às vezes vêm juntas, só para maior visualização: primeiro exemplo - o trabalhador é orientado de que, só com o trabalho em jornada excessiva será capaz de produzir o suficiente para custear suas despesas e ainda receber algo a título de remuneração, pois o valor pago por produção é muito baixo, como acontece, quase sempre, no corte da canade-açúcar e, também, no caso dos trabalhadores bolivianos na "indústria" de confecção em São Paulo; segundo exemplo - o trabalhador é levado a acreditar que pela relação estabelecida, o tomador dos serviços "tem direito" de exigir jornada além até do extraordinário previsto em lei, e que ele rigorosamente desconhece. 
mas condições de trabalho e de remuneração com restrições à autodeterminação do trabalhador. Depois indica, a título de exemplo, algumas situações em que se verifica o trabalho degradante, como: a intermediação fraudulenta do trabalho; a submissão a condições precárias pela falta ou pelo inadequado fornecimento de boa alimentação e água potável; a existência de alojamentos sem condições mínimas; o não fornecimento dos instrumentos para o trabalho e dos equipamentos de proteção individual; o não cumprimento da legislação que rege o trabalho humano etc.

Nucci (2008, p. 691), por sua vez, afirma que, para haver condições degradantes de trabalho "é preciso que o trabalhador seja submetido a um cenário humilhante de trabalho, mais compativel a um escravo do que a um ser humano livre e digno". Continua dizendo que é o bom senso que indicará, para a caracterização, o caminho a percorrer, podendo o juiz utilizar a legislação que rege o trabalho e fixa as condições mínimas.

Capez (2009, p. 346), por seu turno, fala no trabalho "em condições subumanas", enquanto que Prado (2008, p. 64) equipara condições degradantes a condições aviltantes.

De nossa parte, em texto já indicado em nota (In VELLOSO e FAVA, 2006, p. 132133), a respeito de condições degradantes de trabalho, já afirmamos o seguinte:

[...] pode-se dizer que trabalho em condições degradantes é aquele em que há a falta de garantias mínimas de saúde e segurança, além da falta de condições mínimas de trabalho, de moradia, higiene, respeito e alimentação, tudo devendo ser garantido - que deve ser esclarecido, embora pareça claro - em conjunto; ou seja, e em contrário, a falta de um desses elementos impõe o reconhecimento do trabalho em condições degradantes.

Assim, se o trabalhador presta serviços exposto à falta de segurança e com riscos à sua saúde, temos o trabalho em condições degradantes. Se as condições de trabalho mais básicas são negadas ao trabalhador, como o direito de trabalhar em jornada razoável e que proteja sua saúde, garanta-lhe descanso e permita o convívio social, há trabalho em condições degradantes. Se, para prestar o trabalho, - trabalhador tem limitações na sua alimentação, na sua higiene, e na sua moradia, caracteriza-se o trabalho em condições degradantes. Se o trabalhador não recebe o devido respeito que merece como ser humano, sendo, por exemplo, assediado moral ou sexualmente, existe trabalho em condições degradantes.

A partir dessas posições, e à semelhança do que foi feito anteriormente, as condições degradantes de trabalho podem ser caracterizadas com base em três elementos: 1. a existência de uma relação de trabalho; 2 . a negação das condições mínimas de trabalho, a ponto de equiparar - trabalhador a uma coisa ou a um bem; 3. a imposição dessas condições contra a vontade do trabalhador, ou com a anulação sua vontade, por qualquer circunstância que assim o determine ${ }^{12}$.

Definidos os elementos, pode-se oferecer definição de condições degradantes de trabalho. Não faremos sob a forma negativa, nem também de forma analíti-

12 Um exemplo concreto e que, no Ministério Público do Trabalho, tantos de nós presenciamos: o trabalhador que é encontrado prestando serviços em fazenda de forma subordinada, mas, sem CTPS assinada; sem receber salários, sem direito a repouso, diário e semanal; dormindo em barracas de lona, com alimentação escassa e precária, e servindo-se de água - a mesma água -imprópria para suas atividades normais, como beber, tomar banho, lavar seus objetos e utensílios etc., e o que é pior, sem ter como deixar o trabalho, pois fora da fazenda não há trabalho, não há nada, totalmente excluído que é - desse nada, vale ressaltar, é que se vale o tomador dos serviços para reduzi-lo à condição análoga à de escravo, negando sua dignidade. 
ca, exatamente para evitar que, em caso concreto, a presença dessa ou daquela condição de trabalho sirva para impedir o que deve ser caracterizado como trabalho em condições degradantes.

$\mathrm{Na}$ verdade, quando nos referirmos a direitos mínimos, leia-se não todo o conjunto de condições de trabalho, mas sim parte significativa das condições previstas em lei, desde que a falta dessa parte seja suficiente para caracterizar o que os autores chamam de péssimas condições, condições humilhantes, condições subumanas, condições aviltantes, como vimos acima.

Dito isso, condições degradantes de trabalho devem ser definidas como:

Condições impostas pelo tomador de serviços que, em relação de trabalho em que o prestador de serviços tem sua vontade cerceada ou anulada, resultam concretamente na negação de parte significativa dos direitos mínimos previstos na legislação vigente.

\subsection{Restrição de locomoção por dívida contraída}

Por fim, cumpre discutir o último dos modos de execução em estudo, que é a restrição à locomoção do trabalhador, por qualquer meio, em razão de dívida contraída com o empregador ou preposto.

Essa prática ilícita também é conhecida, ou melhor, é mais conhecida como servidão por dívida.

Ela é definida na Convenção Suplementar Relativa à Abolição da Escravatura, do Tráfico de Escravos e das Instituições e Práticas análogas à Escravatura, de 1956, da organização das Nações Unidas' ${ }^{13}$, como:

13 Promulgada pelo Presidente da República, no Brasil, por meio do Decreto $n^{\circ} 58.563$, de $1 \% / 6 / 1966$.
- estado ou a condição resultante do fato de que um devedor se haja comprometido a fornecer, em garantia de uma dívida, seus serviços pessoais ou os de alguém sobre o qual tenha autoridade, se o valor desses serviços não for eqüitativamente avaliado no ato da liquidação de dívida ou se a duração desses serviços não for limitada nem sua natureza definida (art. $1^{\circ}$, letra "a");

Talvez por isso seja comum explicar esse meio de execução fazendo analogia com o modelo de servidão próprio do feudalismo, no período da Idade Média ${ }^{14}$.

Não creio que seja preciso ir tão longe, buscando modelo que não se ajusta de forma precisa ao meio de execução em discussão. Na verdade, o meio reflete a necessidade de repressão a comportamento comum na Amazônia, e que vem desde o Ciclo da Borracha, sendo consequência do que se conhece como "aviamento" ou "sistema de Aviamento", na parte em que esse sistema ditava a relação entre seringalistas e seringueiros ${ }^{15}$.

Comum na relação entre seringueiros e seringalistas, e também chamado de "sistema de barracão", consistia em um sistema de "financiamento compulsório" da atividade dos primeiros pelos últimos.

Os seringueiros, nesse sistema, eram obrigados a entregar o resultado de sua atividade aos seringalistas e, em contrapartida, obrigados também a adquirir todos os produtos necessários à atividade e à própria sobrevivência nos barracões dos últimos.

Ocorre que, como explica Violeta Refkalefsky Loureiro (2004, p. 38),

\footnotetext{
14 E que se aproxima mais da hipótese definida no art. $1^{\circ}$, letra "b", da Convenção mencionada.

15 Mas não só na Amazônia e em razão do aviamento, pois, conforme Neide Esterci, em texto denominado A divida que escraviza (In Trabalho escravo no Brasil contemporâneo, 1999, p. 101), ainda no período da escravidão isso ocorrev no colonato, no Sudeste, nas fazendas de café, e na morada, no Nordeste, nos engenhos de açúcar.
} 
Os preços cobrados por esses artigos eram exorbitantes e os preços pagos pelas bolas de borracha muito baixos. No final, o seringueiro estava sempre devendo ao barracão.

E o que impedia o seringueiro de, percebendo essa dívida perpétua, abandonar o trabalho? Como explica ainda Violeta Loureiro, em estudo com o título A história social e econômica da amazônia (In Estudos e problemas amazônicos: história social e econômica e temas especiais, 1989. p. 19), o fato de que "Os seringais eram cuidadosamente controlados por vigias armados, que atiravam naqueles que tentavam fugir deixando dívidas", além do fato de que os outros seringais só recebiam seringueiro que comprovasse estar quite com o dono do seringal anterior.

Como afirma Samuel Benchimol (1999, p. 142-143), "Administrar um seringal era tarefa bastante difícil e complexa" e, entre as múltiplas funções dos seringalistas, uma delas era a de "justiçar" seringueiros fujões.

Seringueiro, então, no sistema do aviamento, pela "dívida" que não era capaz de pagar, e pelo fato de que, por esse motivo, não podia deixar o garimpo, era claramente pessoa reduzida à condição análoga à de escravo.

Como diz Márcio Souza (1990, p. 48), o seringueiro,

Era aparentemente livre, mas a estrutura concentracionária do seringal o levava a se tornar um escravo econômico e moral do patrão. Endividado, não conseguia mais escapar. Se tentava fuga, isto podia significar a morte ou castigos corporais rigorosos.

Da mesma forma Roberto Santos (1980, p. 165-166), que explica que nos serin- gais havia guarda armada para impedir que os seringueiros "em débito" fugissem, colaborando a polícia oficial com essa prática, remetendo de volta os que capturasse. Ensina ainda que a contabilidade nas relações entre as partes era controlada pelo seringalista, que "detinha a possibilidade de fazer os números dançarem ao compasso de seus interesses".

Vejamos agora o que diz José Carlos Aragão Silva, em Conversa bonita: o aliciamento e os caminhos que levam à escravidão por dívida (In CERQUEIRA e outros, 2008. p. 213 ):

A vigilância permanente tinha como objetivo evitar a fuga de peões, manter a disciplina, assim como instaurar a sensação de constante controle sobre o empregado, como se ele se encontrasse numa fábrica do século XVIII, onde, do alto, os patrões vigiavam tudo, instalando a sensação de visão panóptica referida por Foucault (1989).

Contudo, além dos "onipresentes pistoleiros" (sutton, 1994) existiam outros mecanismos mais eficientes que prendiam os trabalhadores de Presidente Dutra na Fazenda Santo Antônio do Indaiá, e que ainda continuam a aprisionar peões no sul do Pará. Trata-se das correntes invisíveis da dívida, as quais, no caso aqui estudado, haviam sido estabelecidas a partir do momento em que os peões receberam o "abono" do empreiteiro.

Esse relato, praticamente idêntico aos anteriores, relativos ao Ciclo da Borracha, que inicia no Século XIX, é de situação vivida por trabalhadores maranhenses no final de 1990.

Isso revela que o meio de execução que no artigo 149 do Código Penal é denominado de "Reduzir alguém a condição análoga à de escravo, [...] restringindo, por qualquer meio, sua locomoção em ra- 
zão de dívida contraída com o empregador ou preposto" está claramente inspirado na necessidade de reprimir uma prática que é secular na Amazônia; que, conforme vimos com Esterci, ocorreu em outros locais do País; e que se traduz na retirada do direito do trabalhador de cessar o trabalho e deixar o local em que - serviço é prestado, somente pelo fato de ter contraído dívida com o tomador dos serviços, ou, como é bastante comum, com seus prepostos, com destaque para os "gatos"16, desde o aliciamento.

A prática, já nefasta por si só, agrava-se pelo fato de que a "dívida", via de regra, é artificialmente criada, quer porque os valores cobrados dos trabalhadores estão muito acima do preço usual, quer porque o tomador dos serviços, que tem o risco da atividade, transfere parte desse risco cobrando dos trabalhadores até pelos instrumentos de trabalho, necessários à execução da atividade e, portanto, de inteira responsabilidade do primeiro.

Em relação a esse último aspecto, Ricardo Rezende Figueira (2004, p. 174) narra a situação na qual trabalhadores, na fazenda Flor da Mata, no sul do Pará, em 1997, foram levados pelo "gato" fogoió e por peões armados a "fazer a cantina", ou seja "adquirir a comida e os instrumentos de trabalho do próprio gato".

No plano do Direito, segundo Fernando Capez (2009, p. 346), trata-se de cercear, obstar a liberdade de ir e vir da pessoa. Para o autor,

A vítima se encontra obrigada a trabalhar sem permissão para deixar o local até a quitação total da dívida contraída com o patrão ou preposto.

16 "Gato" deve ser entendido como o indivíduo que, a mando do tomador dos serviços, alicia os trabalhadores para o trabalho nas fazendas, sob sua direção ou não, e que é o responsável, via de regra, por fazer o primeiro adiantamento em dinheiro para que os trabalhadores deixem com suas famílias ou saldem suas dívidas.
Neste último caso, geralmente não há pagamento em dinheiro, mas mediante compensação de débito, quase sempre de difícil quitação.

Essa difícil quitação, a propósito, é de fácil compreensão, bastando que nos lembremos de Roberto Santos, citado acima falando do aviamento na época da borracha, quando este indica que a controle da dívida pertencia ao tomador dos serviços, permitindo a este fazê-la "dançar" (leia-se aumentar) conforme seus interesses.

É como diz Pierangeli (2007, p. 160), a respeito da dívida:

Uma dívida que nunca fica saldada, que mensalmente aumenta por meio de expedientes ilícitos, inclusive da fraude ou incidência de juros extorsivos, não obstante o trabalho desempenhado pela vítima por todo o mês.

Feita essa exposição a respeito de como ocorre a conduta no modo de execução em discussão, de seus antecedentes, e da visão doutrinária a respeito, cabe indicar os elementos que caracterizam, em conjunto, a restrição de locomoção do trabalhador, por qualquer meio, em razão de dívida contraída: 1. a existência de uma relação de trabalho; 2 . a presença de uma dívida de qualquer natureza, lícita ou ilicitamente constituída, que tenha - trabalhador para com o tomador de seus serviços ou com seus prepostos; 3 . o impedimento ao direito do trabalhador de deixar o trabalho, por meio da coação, que pode ser física ou moral, ou por qualquer outro meio que impossibilite o seu deslocamento ${ }^{17}$, em razão da dívida referida no item 2 .

17 A esse respeito, Luiz Regis Prado (2008, p. 64) ensina que "o agente pode se utilizar da ameaça, violência, fraude, desde que idôneos à sujeição do sujeito passivo ao seu domínio". 
Nesse sentido, acreditamos que a restrição de locomoção do trabalhador, por qualquer meio, em razão de dívida contraída, para os fins do art. 149 do Código Penal, deve ser definida como:

A restrição ao direito do trabalhador de deixar o trabalho, por coação ou qualquer outro meio, em razão de dívida, lícita ou ilicitamente constituída, deste para com o tomador de seus serviços ou com seus prepostos.

É que, na definição acima, pensamos, estão presentes os elementos básicos desse meio de execução, que é a presença da relação de trabalho, indispensável hoje para a caracterização do tipo penal, e - fato de que o trabalhador tem 0 seu direito de deixar o trabalho obstado, em razão da "obrigação" que teria para com o tomador de seus serviços ou com os prepostos deste, em razão de dívida.

A propósito da dívida, embora tenhamos visto mais acima que o normal é inflá-la a partir da cobrança de preços abusivos, bem como cobrar o que não é devido, como os instrumentos para o trabalho e outros bem necessários à realização da atividade, todos de responsabilidade, no tocante ao fornecimento, do tomador dos serviços, é preciso ressaltar sempre que pouco importa sua origem lícita ou ilícita, pois não é possível obstar, em qualquer hipótese, a liberdade de locomoção do trabalhador em razão de dívida contraída em relação de trabalho.

\section{Conclusão}

Oferecida uma caracterização jurídica para o crime de reduzir a pessoa à condição análoga à de escravo e, principalmente, as definições de seus modos típicos de execução, gostaríamos de, antecipan- do críticas, concluir dizendo que, de fato, especialmente em relação aos modos de execução, ainda pode pairar algum tipo de incerteza, pois, à impossibilidade de oferecer definições absolutamente precisas, a identificação ainda dependerá, como diz Nucci, citado mais atrás, do bom senso do intérprete.

Essa incerteza, todavia, acreditamos, desaparece ou é ao menos amenizada quando, ao lado das definições, agregamos os elementos caracterizadores das hipóteses de redução da pessoa à condição análoga à de escravo, pois esses elementos são concretos e suficientes para a tipificação.

É que, o importante é ter indicadores capazes de, com o mínimo de precisão que $\circ$ Direito impõe - e que jamais será absoluta -, identificar os casos em que a conduta humana deve ser caracterizada como típica para o cometimento do crime de impor a alguém o trabalho em condições análogas à escravidão.

\section{REFERÊNCIAS}

BENCHIMOL, Samuel. 1999. Amazônia - formação social e cultural. Manaus, Editora Valer; Editora da Universidade do Amazonas.

BITENCOURT, Cezar Roberto. 2009. Tratado de direito penal, 2: parte especial: dos crimes contra a pessoa. 9 ed. São Paulo, Saraiva.

BRITO FILHO, José Claudio Monteiro de. 2010. Trabalho decente. 2 ed. São Paulo, LT.

CAPEZ, Fernando. 2009. Curso de direito penal, 2: parte especial. 9 ed. São Paulo, Saraiva.

CERQUEIRA, Gelba Cavalcante de e outros (Org.). 2008. Trabalho escravo contemporâneo no brasil: contribuições críticas para sua análise e denúncia. Rio de Janeiro, Editora UFRJ.

ESTUDOS E PROBLEMAS AMAZÔNICOS: HISTÓRIA SOCIAL E ECONÔMICA E TEMAS ESPECIAIS. 1989. Belém, Instituto do Desenvolvimento Econômico-Social do Pará (IDESP). 
FIGUEIRA, Ricardo Rezende. 2004. Pisando fora da própria sombra: a escravidão por dívida no Brasil contemporâneo. Rio de Janeiro, Civilização Brasileira.

GRECO, Rogério. 2008. Curso de direito penal: parte especial. 5 ed. Niterói - RJ, Impetus. v. 2.

KANT, Immanuel. 2003. Fundamentação da metafísica dos costumes. Traduzida do alemão por Paulo Quintela. Lisboa - Portugal, Edições 70.

LOUREIRO, Violeta Refkalefsky. 2004. Amazônia: estado, homem, natureza. 2 ed. Belém, Cejup.

MELO, Luis Antônio Camargo de. 2013. Premissas para um eficaz combate ao trabalho escravo. Revista do Ministério Público do Trabalho. São Paulo, LTr, n. 26, p. $11-33$, setembro/2003.

NUCCl, Guilherme de Souza. 2008. Código penal comentado. 9 ed. São Paulo, Editora Revista dos Tribunais.

PEREIRA, Cícero Rufino. 2007. Efetividade dos direitos humanos trabalhistas: o ministério público do trabalho e o tráfico de pessoas: 0 protocolo de Palermo, a convenção n. 169 da OIT, o trabalho escravo, a jornada exaustiva. São Paulo, LTr.
PIERANGELI, José Henrique. 2007. Manual de direito penal brasileiro. 2 ed. São Paulo, Editora revista dos Tribunais, volume 2: parte especial.

PINHO, Ana Cláudia de Bastos e GOMES, Marcus Alan de Melo (Org.). 2010. Direito penal e democracia. Porto Alegre, Núria Fabris.

PRADO, Luiz Regis. , 2008. Direito penal: parte especial - arts. 121 a 196. 2 ed. São Paulo, Editora Revista dos Tribunais.

RABENHORST, Eduardo Ramalho. 2001. Dignidade humana e moralidade democrática. Brasília, Brasília Jurídica.

SANTOS, Roberto. 1980. História econômica da amazônia: 1800-1920. São Paulo, T.A. Queiroz.

SOUZA, Márcio. 1990. O empate contra chico mendes. São Paulo, Marco Zero.

TRABALHO ESCRAVO NO BRASIL CONTEMPORÂNEO (Coletânea). 1999. São Paulo, Edições Loyola; Comissão Pastoral da Terra: Goiânia.

VELLOSO, Gabriel, e FAVA, Marcos Neves (Coord.). 2006. Trabalho escravo contemporâneo: o desafio de superar a negação. São Paulo, LTr. 